\title{
A long term calibration and verification of a submerged aquatic vegetation model for Lake Okeechobee
}

\author{
Kang-Ren $\mathrm{Jin}^{1 *}$ and Zhen-Gang Ji ${ }^{2}$
}

\begin{abstract}
Introduction: Submerged aquatic vegetation (SAV) has multiple functions in Lake Okeechobee. It provides critical habitat for fish and wildlife, stabilizes sediments, reduces phosphorus (P) concentration in the water column by preventing re-suspension of P-rich sediments, and provides a substrate for attached algae, which also helps to remove P from the water column. Ten year water quality and SAV growth simulations are presented and compared with observed SAV and water quality data collected in the nearshore zone in Lake Okeechobee.

Methods: The SAV theory and approach used in the LOEM are modified from the Chesapeake Bay model and incorporate three state variables: shoots (above the bed sediment), roots (in the bed sediment), and epiphytes (attached to the shoots). The SAV model has direct linkages with the water quality model, including (1) a link between the growth and decay of SAV and the nutrient pool of the water quality model; (2) a link between the photosynthesis and respiration of SAV and dissolved oxygen dynamics, and (3) the ways in which settling of particulate organic matter and nutrient uptake affect nutrient levels in the water column and in the sediment bed.

Results: Total suspended solids affect light attenuation and are another major driving factor for SAV growth in the nearshore and littoral zone area. The model performs reasonably well in reproducing the spatial distribution of SAV.

Conclusions: The theoretical analysis and model sensitivity tests indicate that SAV growth is primarily controlled by light and nutrients. The light available for SAV growth depends on the water depth and the turbidity. In this full scale simulation, the water depth comes from the LOEM hydrodynamic model, and the turbidity depends on the suspended sediment concentration and algal concentration.
\end{abstract}

Keywords: Submerged aquatic vegetation (SAV); SAV modeling; Lake Okeechobee; Long term simulation

\section{Introduction}

Environmental effects in Lake Okeechobee must be carefully evaluated, owing to the complex nature of the ecosystem, both in terms of its distinct ecological zones (pelagic, benthic, nearshore, littoral) and the diverse array of biota that depend on these water resources (Havens et al. 1996a). Submerged aquatic vegetation (SAV) is often a desirable component of shallow lakes and wetlands. Management activities are often directed to ensure its continual presence. SAV is an important habitat, providing refuge to juvenile fish and shellfish and providing a food

\footnotetext{
* Correspondence: kjin@sfwmd.gov

'South Florida Water Management District, P.O. Box 24680, West Palm Beach, FL 334164680, USA

Full list of author information is available at the end of the article
}

source for fish and waterfowl (Havens et al. 2005). The assessment of SAV provides a direct link between water quality (nutrients, chlorophyll $a$, and suspended sediments) and ecologically and economically important species (Havens et al. 1996b).

SAV plays a key role in shallow lakes because it indirectly influences the biomass of phytoplankton and water column transparency through a variety of mechanisms (Havens and Gawlik 2005). These include stabilization of sediments by roots, reduction of shearing stress to sediment surfaces, uptake of nutrients by attached periphyton, and precipitation of phosphorus with calcium when intense photosynthesis results in high water column $\mathrm{pH}$ (Murphy and Yesaki 1983; Dennison et al. 1993; Scheffer 1998; Vermaat et al. 2000; Havens et al. 1999). Lakes with 
dense SAV typically have clear water and low phytoplankton biomass; however, if the plants are lost, the lake waters can become very turbid even under normal wind speeds (Scheffer 1989, 1998). Even if a shallow area (where SAV grows) is adjacent to a deeper and open area (where typically no SAV grows), the presence of SAV will still keep the shallow water clear (Scheffer et al. 1994). This is the situation that exists in Lake Okeechobee as suggested by Phlips et al. (1993) and then documented by Havens et al. (2004b). The nearshore zone can switch from a SAV/ clear-water state to a phytoplankton/turbid-water state when water levels shift from low to high for prolonged periods (Havens et al. 1995, 2001, 2004a, b; Havens and Walker 2002; Havens 2003).

A series of hurricanes from 2004 to 2005 destroyed most SAV along the nearshore zone in Lake Okeechobee. The hurricanes resulted in a dramatic increase in total suspended solids (TSS), turbidity, and total phosphorus (TP) within the water column of the lake in the following several years (James et al. 2008). An increase in thickness of the unconsolidated sediment layer is attributed to an increase in sediment during the storms and post-storm settling of resuspended sediment. The unconsolidated layer was much more easily resuspended, even under a light wind conditions, resulting in sustained higher TSS and nutrient concentrations and lower light transparency in the water column (Jin et al. 2011). Reduced light transparency is the key driver to reduced coverage of SAV and contributed to the decline in biomass of SAV and phytoplankton in the 3 years after the hurricanes until the historical drought in 2007-2009. The water depth was so low that light could reach the bottom of the lake, even when the water was still very turbid. The SAV seeds were then able to start to geminate, and SAV in the nearshore zone has since recovered (Jin et al. 2011).

SAV is a major component of the Lake Okeechobee ecosystem and affects both critical fauna and water quality. Because SAV responds to water clarity, which is affected by the amount of nutrients and algae present in the water, it is also an important performance measure for evaluating the health of Lake Okeechobee. Healthy submerged and emergent plant communities offer good habitats for fish and wading birds and good water quality in nearshore regions of the lake, which are those generally used by wildlife and society. Long-term restoration goals include maintaining an optimal range of water depths in the lake to support healthy SAV communities. The SAV removes nutrients from the water column, creates habitats for the fish communities, and is a major contributor to the nearshore food web. The SAV performance measure indicates that SAV in the nearshore region should consistently cover over 40,000 acres (ac) (about 9\% of the lake area), with vascular plants comprising $50 \%$ of the SAV composition. A complete understanding of the effects of
SAV on the lake ecosystem will require a careful integration of the results of water quality, SAV analysis, and outputs from a spatially intensive Lake Okeechobee hydrodynamic, water quality and SAV model.

There are only a few SAV models that have been developed for environmental study. One of the major reasons for this is the shortage of data to calibrate the model for the study area. Another reason is the SAV model cannot run independently; an integrated hydrodynamic, water quality, sediment, or even wind-wave model is required to provide the needed instant hydrodynamics, water quality light attenuation, sediment contraction, and other environmental parameters. The well known Chesapeake Bay SAV model is coupled to an eutrophication model of the Chesapeake Bay 3D model (Cerco and Moore 2001). Sheng et al. $(2001,2003)$ introduced a 3-D curvilineargrid hydrodynamics integrated model (CH3D-IMS) to Indian River Lagoon, Florida. This model can simulate the following processes: hydrodynamics/salinity, waves/sediments, water quality, light attenuation, and SAV (sea grass growth). However, the above SAV models apply to estuary or coastal areas.

The Lake Okeechobee Environment Model (LOEM) meets the above criteria and has been applied to freshwater, making it ideal for this study. The LOEM (Jin et al. 2000, 2002; Jin and Ji 2001) was calibrated and verified with data collected by the South Florida Water Management District (SFWMD) to predict long-term hydrological conditions, nutrient conditions, and environmental impacts in the lake under different water level management scenarios (Jin and Ji 2004). The LOEM contains 2,126 horizontal grid cells and five vertical layers. The primary hydrodynamic and sediment transport driving forces are wind waves (Dean and Dalrymple 1991), surface wind stresses, and inflows/outflows. The LOEM is used to provide critical information about spatial variation in response to the lake, in terms of physical, chemical, and biological (submerged vegetation) conditions (Jin et al. 2007; Jin and Ji 2005), for relatively short simulation periods. It can predict the key variables in the fate, dispersal, and transportation of conservative stressors (such as chloride and sulfate) entering the lake from particular locations around its perimeter.

The objectives of this research are to verify and validate the SAV model and integrate it into the LOEM to examine the time sequence of concentrations of stressors as they are mixed throughout the lake, and thereby identify the regions where biota are expected to be most affected under different management scenarios (high/low stage, hurricanes, and sediment dredging/management). The assumption of the SAV abundance distribution is affected by at least three factors: area available for SAV growth, conditions suited for SAV growth (water depth, water clarity, nutrients), and tropical storms (hurricanes). The 
hypotheses related to SAV growth (intensity) and expansion are whether (1) light attenuation is the most important factor for SAV growth; (2) phosphorus is the key factor for SAV expansion; (3) water depth impacts SAV growth; and (4) SAV growth is density dependent. The model parameter sensitivity analysis using the LOEM will address the above hypotheses.

\section{Methods}

\section{Governing equations for the SAV model}

SAV communities are diverse and grow underwater. A few species of SAV have flowers that extend above the water surface. There are hundreds of known SAV species in freshwater and marine habitats. The definition of SAV usually excludes algae, floating plants, and plants that grow above the water surface (Ji 2008). The SAV variables are shoots, roots, and attached periphyton (epiphytes). The SAV theories and algorithms currently being developed for the LOEM primarily originated from the SAV modeling in Florida Bay (Cerco et al. 2002) and the modeling work of Hamrick [1992, 1994; AEE (2012) A rooted aquatic plant and epiphyte algae sub-model for EFDC, unpublished] and Hamrick and Wu (1997). But the LOEM SAV model has its own improvements including the following:

(1) Storm event (hurricane) impacts on light attenuation and SAV growth are incorporated. Hurricanes can cause huge sediment resuspension and increase suspended sediment concentrations in the water column. Hurricanes can also result in a flush of watershed nutrients and a large amount of water into the lake and increase the lake water depth. The combination of high levels of suspended solids and high water depth reduces the light available to the SAV, which then reduces the SAV growth.

(2)A shelf-shading effect is included. Shelf-shading affects the production or growth rate for plant shoots. Self-shading by shoots is incorporated into density-limiting functions in the model, since shoot abundance will ultimately be limited by the reduced light available to the SAV growth.

(3) The effects of SAV respiration and production are accounted for. These are additional terms added to the effects of SAV production. The production of shoots (RPS) and epiphytes (RPE) increases dissolved oxygen (DO) in the water column, while the respiration of shoots and epiphytes decreases DO in the water column.

(4) The LOEM SAV module completes the coupling of DO and other parameters with SAV growth in the water column.
The integrated 3D LOEM hydrodynamic, sediment transport, water quality, and diagenesis equations are presented in Jin and Ji (2001, 2004, 2005), Ji and Jin (2006), and Jin et al. (2000, 2002, 2007). The SAV model incorporates three state variables: shoots (above the bed sediment), roots (in the bed sediment), and epiphytes (attached to the shoots). Shoots and epiphytes exchange nutrients with the water column component of the water quality model. Roots exchange nutrients with the bed sediment diagenesis component of the water quality model (Jin et al. 2007). The kinetic mass balance equations for rooted plant shoots, roots, and epiphyte algae growing on the shoots are from Cerco et al. (2002) and Hamrick (2004, A rooted aquatic plant and epiphyte algae sub-model for EFDC, unpublished):

$$
\begin{aligned}
\frac{\partial(R P S)}{\partial t}= & \left(\left(1-F_{P R P R}\right) \bullet P_{R P S}-R_{R P S}-L_{R P S}\right) R P S \\
& +J R P_{R S} \\
\frac{\partial(R P R)}{\partial t}= & F_{P R P R} \bullet P_{R P S} \bullet R P S-\left(R_{R P R}+L_{R P R}\right) R P R-J R P_{R S}, \text { and } \\
\frac{\partial(R P E)}{\partial t}= & \left(P_{R P E}-R_{R P E}-L_{R P E}\right) R P E
\end{aligned}
$$

where $t$ is time (days); RPS is the rooted plant shoot biomass $\left(\mathrm{g} \mathrm{C} \mathrm{m}^{-2}\right)$; $F_{\text {PRPR }}$ is the fraction of production directly transferred to roots $\left(0<\mathrm{F}_{\mathrm{PRPR}}<1\right)$; $\mathrm{P}_{\mathrm{RPS}}$ is the production rate for plant shoots $\left(\right.$ day $\left.^{-1}\right) ; R_{\mathrm{PRS}}$ is respiration rate for plant shoots $\left(\right.$ day $\left.^{-1}\right)$; $\mathrm{L}_{\mathrm{RPS}}$ is the non respiration loss rate for plant shoots $\left(\right.$ day $\left.^{-1}\right)$; $\mathrm{JRP}_{\mathrm{RS}}$ is the carbon transport positive from roots to shoots $\left(\mathrm{g} \mathrm{C} \mathrm{m}^{-2}\right.$ day $\left.^{-1}\right)$; RPR is rooted plant root biomass $\left(\mathrm{g} \mathrm{C} \mathrm{m}^{-2}\right) ; \mathrm{R}_{\mathrm{RPR}}$ is the respiration rate for plant roots $\left(\right.$ day $\left.^{-1}\right) ; L_{R P R}$ is the non respiration loss rate for plant roots $\left(\right.$ day $\left.^{-1}\right)$; RPE is the rooted plant epiphyte biomass $\left(\mathrm{g} \mathrm{C} \mathrm{m}^{-2}\right) ; \mathrm{P}_{\mathrm{RPE}}$ is the production rate for epiphytes $\left(\right.$ day $\left.^{-1}\right) ; R_{P R E}$ is the respiration rate for epiphytes $\left(\right.$ day $\left.^{-1}\right)$; and $L_{R P E}$ is the non-respiration loss rate for epiphytes $\left(\right.$ day $\left.^{-1}\right)$.

The governing equation for shoots, Eq. (1), establishes a balance between sources and sinks of SAV biomass in the water column. The governing equation for roots, Eq. (2), establishes a balance between sources and sinks of SAV biomass in the sediment bed. An additional state variable is used to account for shoot detritus at the bottom of the water column:

$$
\frac{\partial(R P D)}{\partial t}=F_{R P S D} \cdot L_{R P S} \cdot R P S-L_{R P D} \cdot R P D
$$

where RPD is the rooted plant shoot detritus biomass $\left(\mathrm{g} \mathrm{C} \mathrm{m}^{-2}\right.$ ); $\mathrm{F}_{\mathrm{RPSD}}$ is the fraction of shoot loss to detritus $\left(0<\mathrm{F}_{\mathrm{RPSD}}<1\right)$; and $\mathrm{L}_{\mathrm{RPD}}$ is the decay rate of detritus $\left(\right.$ day $\left.^{-1}\right)$. 
SAV growth can be limited by light, temperature, water column nutrients, sediment column nutrients, salinity, shading by phytoplankton or epiphytes, grazing, hurricanes, and tropical storms. If light, nutrients, or water temperatures are at levels that are not optimal, they can be considered limiting factors for SAV growth. Light availability often plays a key role in SAV development. High concentrations of suspended sediments, algae, or floating aquatic plants and/or hurricanes are not conducive to SAV growth.

The production or growth rate for plant shoots is given by:

$$
P_{R P S}=P M_{R P S} f_{1 W}(N) f_{1 B}(N) f_{2}(I) f_{3}(T) f_{4}(S) f_{5}(R P S)
$$

where:

$\mathrm{PM}_{\mathrm{RPS}}=$ maximum growth rate under optimal conditions for plant shoots $\left(\right.$ day $\left.^{-1}\right)$

$\mathrm{f}_{1}(\mathrm{~N})=$ effect of suboptimal nutrient concentration $\left(0 \leq \mathrm{f}_{1} \leq 1\right)$

$\mathrm{w}=$ water column

$\mathrm{b}=\mathrm{bed}$

$\mathrm{f}_{2}(\mathrm{I})=$ effect of suboptimal light intensity $\left(0 \leq \mathrm{f}_{2} \leq 1\right)$

$f_{3}(T)=$ effect of suboptimal temperature $\left(0 \leq f_{3} \leq 1\right)$

$\mathrm{f}_{4}(\mathrm{~S})=$ effect of salinity on freshwater plant shoot growth $\left(0 \leq \mathrm{f}_{4} \leq 1\right)$

$f_{5}($ RPS $)=$ effect of shoot self-shading on shoot growth $\left(0 \leq \mathrm{f}_{5} \leq 1\right)$

Here, $f_{1}, f_{2}, f_{3}$, and $f_{4}$ are defined by Cerco et. al. (2002) and Hamrick (2004, A rooted aquatic plant and epiphyte algae sub-model for EFDC, unpublished). $f_{5}$ is the representation of self-shading by shoots and is to incorporate a density-limiting function into the model, since shoot abundance will ultimately be limited by the reduced light available to the SAV growth. The effect of shoot selfshading on shoot growth is given by:

$$
f_{5}(R P S)=e^{-K_{S H} \cdot R P S}
$$

where $K_{\mathrm{SH}}$ is the attenuation due to shoot self-shading $\left(\mathrm{m}^{2} / \mathrm{g}\right)$.

The respiration rate for plant shoots is expected to be temperature dependent:

$$
R_{R P S}=\left\{\begin{array}{c}
R M_{R P S} \cdot \exp \left(-K T R 1_{R P S}\left[T-T R 1_{R P S}\right]^{2}\right) \quad \text { if } T \leq T R 1_{R P S} \\
R M_{R P S} \quad \text { if } \quad T R 1_{R P S}<T<T R 2_{R P S} \\
R M_{R P S} \cdot \exp \left(-K T R 2_{R P S}\left[T-T R 2_{R P S}\right]^{2}\right) \quad \text { if } T \geq T R 2_{R P S}
\end{array}\right.
$$

where:

$\mathrm{RM}_{\mathrm{RPS}}=$ maximum respiration rate for shoots $\left(\right.$ day $\left.^{-1}\right)$

$\mathrm{T}=$ temperature $\left({ }^{\circ} \mathrm{C}\right)$ provided from the hydrodynamic model
$\mathrm{TR} 1_{\mathrm{RPS}}<\mathrm{T}<\mathrm{TR} 2_{\mathrm{RPS}}=$ optimum temperature range for shoot respiration $\left({ }^{\circ} \mathrm{C}\right)$

$\mathrm{KTR} 1_{\mathrm{RPS}}=$ effect of temperature below $\mathrm{TM} 1_{\mathrm{RPS}}$ on shoot respiration $\left({ }^{\circ} \mathrm{C}^{-2}\right)$

$\mathrm{KTR} 2_{\mathrm{RPS}}=$ effect of temperature above $\mathrm{TM} 2_{\mathrm{RPS}}$ on shoot respiration $\left({ }^{\circ} \mathrm{C}^{-2}\right)$

The non-respiration loss rate for shoots is expected to be constant.

The respiration rate for plant roots is expected to be temperature dependent.

$$
R_{R P R}=\left\{\begin{array}{c}
R M_{R P R} \cdot \exp \left(-K T R 1_{R P R}\left[T-T R 1_{R P R}\right]^{2}\right) \quad \text { if } T \leq T R 1_{R P R} \\
R M_{R P S} \text { if } T R 1_{R P S}<T<T R 2_{R P S} \\
R M_{R P R} \cdot \exp \left(-K T R 2_{R P R}\left[T-T R 2_{R P R}\right]^{2}\right) \quad \text { if } T \geq T R 2_{R R P}
\end{array}\right.
$$

where:

$\mathrm{RM}_{\mathrm{RPR}}=$ maximum respiration rate for roots $\left(\right.$ day $\left.^{-1}\right)$

$\mathrm{T}=$ temperature $\left({ }^{\circ} \mathrm{C}\right)$ provided from the hydrodynamic model

$\mathrm{TR} 1_{\mathrm{RPR}}<\mathrm{T}<\mathrm{TR} 2_{\mathrm{RPR}}=$ optimal temperature range for root respiration $\left({ }^{\circ} \mathrm{C}\right)$

$\mathrm{KTR} 1_{\mathrm{RPR}}=$ effect of temperature below $\mathrm{TM} 1_{\mathrm{RPR}}$ on root respiration $\left({ }^{\circ} \mathrm{C}^{-2}\right)$

$\mathrm{KTR} 2_{\mathrm{RPR}}=$ effect of temperature above $\mathrm{TM} 2_{\mathrm{RPR}}$ on root respiration $\left({ }^{\circ} \mathrm{C}^{-2}\right)$

The non-respiration loss rate for roots is expected to be constant.

\section{Integration of LOEM and SAV model}

The SAV model must be coupled with a hydrodynamics, sediment, and water quality model since SAV growth is dependent on nutrient uptake (generated by water quality modeling), sunlight (light attenuation, calculated from hydrodynamic/sediment/transport model), and water depth (generated from hydrodynamic modeling).

In the hydrodynamic modeling, water inflow and outflow are critical to the mass balance in the lake. Based on the measured data, efforts are made to ensure that appropriate water inflows and outflows are used in the model. As discussed, water evaporation is also important for the water balance in the lake. The LOEM calculates the water evaporation rate based on measured air temperature, relative humidity, air pressure, wind speed, and the modeled water temperature. Figure 1 is the comparison between the modeled and the measured lake stage at LZ40. The red line shows measured data and the black line shows the model estimate. The relative RMS error was $4.6 \%$. It is evident that the model simulated the lake depth very well. The relative RMS error was $4.6-5.2 \%$ for the other three in-lake stations (L001, L005, and L006) (Jin et al. 2011; AEE 2012). 


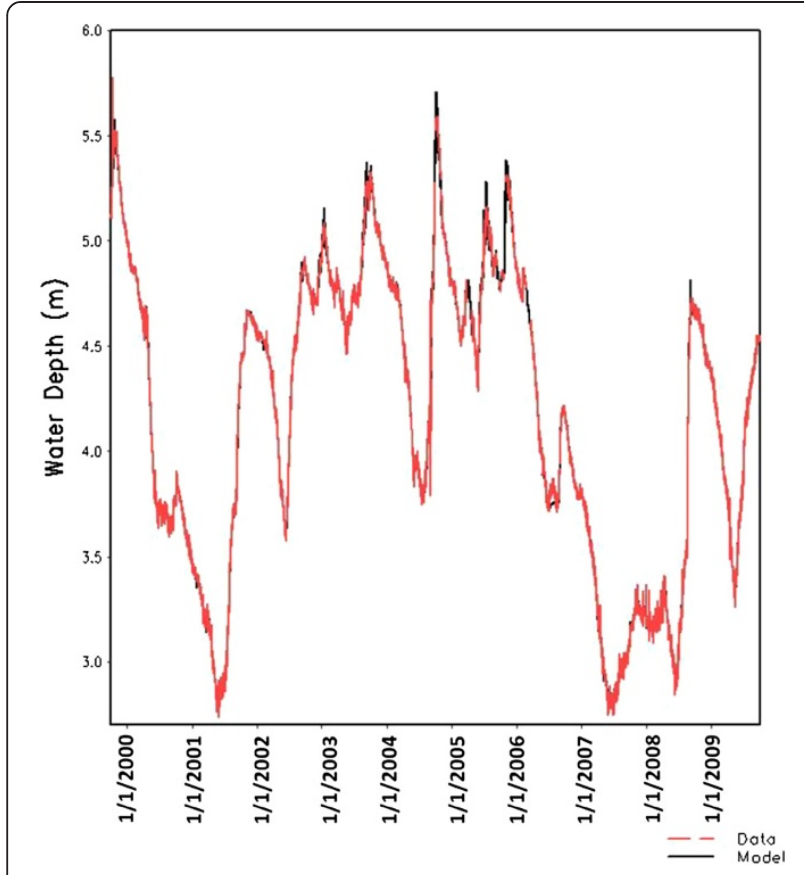

Figure 1 Modeled and measured lake stage at LZ40 from $10 / 1 / 1999$ to $12 / 31 / 2009$.

Sediment transport, settlement, and suspension play important roles in the fate of contaminants and their transport, water quality, and eutrophication processes. TSS is important to water quality and eutrophication processes because of their influence on density, light penetration, and nutrient availability. Increased TSS reduces light penetration in the water column, thus influencing water temperature, which in turn affects biological and chemical reaction rates. The strength of solar radiation in the water column also directly affects algae and vegetation growth. Nutrient concentrations are also affected by TSS through absorption and settling. In summary, light and nutrient availability, which are closely related to TSS concentration, largely control algal production.

The LOEM sediment module was calibrated, verified, and validated using the sediment data in 2000, 2001, and 2002, respectively (Jin and Ji 2004, 2005). The theoretical analysis and model sensitivity tests indicate that SAV growth is primarily controlled by light and nutrients (AEE 2012). In order to calibrate the SAV model, key parameters such as TSS and nutrients (SRP, TP, etc.) should be calibrated and verified. TSS and water quality simulations from $10 / 1 / 1999$ to $12 / 31 / 2009$, a duration of 3,653 days, were conducted and compared with the data from 15 stations for the same time period. For comparisons between model results and observations for the eight water quality parameters [DO, chlorophyll (CHLA), TP, soluble reactive phosphorus (SRP), total suspended solids (TSS),TKN, $\mathrm{NO}_{2}+\mathrm{NO}_{3}$ (NOx), and temperature
(T)], data from Station LZ40 (Figure 2, Table 1) areused to represent the 15 stations available in Lake Okeechobee due to its location at the center of the lake. Statistics regarding the water quality parameters and $\mathrm{T}$ are presented in Table 1. The last column in Table 1 shows the relative root mean square error (RRMSE) over the variance range. The average RRMSE is $17.14 \%$. In the calculation of DO relative errors, traditionally, the mean DO rather than the DO variation has been used (e.g., Martin and McCutcheon 1999; USEPA 1999).

The statistics of overall model performance are summarized in Table 2. The root mean square errors and relative errors at each station are calculated. Table 2 gives the summary of station-averaged RRMSE from 1999 to 2009. A total of eight variables are calculated at each station. They are DO, CHLA, TP, SRP, total Kjeldhal N (TKN), NOx, TSS, and T. Table 2 shows that the mean relative error averaged over the eight state variables at the 15 stations is $22.6 \%$. The measured $\mathrm{NH}_{4}$ data are unreliable due to measurement limitation, therefore, the $\mathrm{NH}_{4}$ time series of the model data comparisons in the figures are for reference only.

In previous studies, water quality modeling results have often been presented as spatial and temporal averages. For instance, the Chesapeake Bay Model (Cerco and Cole 1994) compared model results with observations that were averaged by month and over aggregated grid subdivisions.

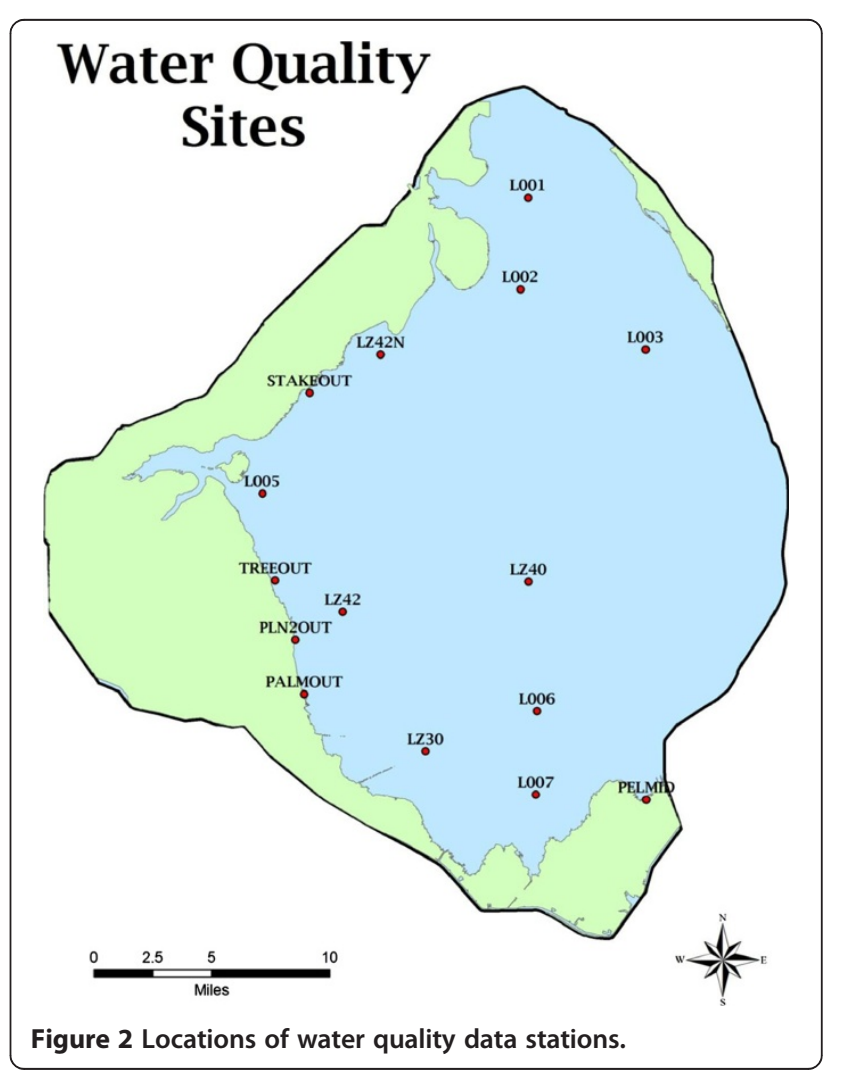


Table 1 Error analysis of observed data and modeled results at LZ40 from 1999 to 2009

\begin{tabular}{lllllll}
\hline Parameter name & Number of data points & Obs. mean & Modeled mean & RMS err. & Obs. change & RRMSE (\%) \\
\hline DO $(\mathrm{mg} / \mathrm{l})$ & 121 & 8.081 & 8.663 & 0.945 & 8.730 & 11.696 \\
$\mathrm{CHLA}(\mu \mathrm{g} / \mathrm{l})$ & 122 & 16.179 & 17.321 & 31.419 & 342.700 & 9.168 \\
$\mathrm{TP}(\mathrm{mg} / \mathrm{l})$ & 127 & 0.188 & 0.130 & 0.146 & 1.272 & 11.443 \\
$\mathrm{SRP}(\mathrm{mg} / \mathrm{l})$ & 126 & 0.056 & 0.070 & 0.030 & 0.104 & 28.503 \\
$\mathrm{TKN}(\mathrm{mg} / \mathrm{l})$ & 127 & 1.486 & 1.298 & 0.897 & 9.000 & 9.961 \\
$\mathrm{NOx}(\mathrm{mg} / \mathrm{l})$ & 117 & 0.292 & 0.047 & 0.335 & 0.829 & 40.461 \\
$\mathrm{TSS}(\mathrm{mg} / \mathrm{l})$ & 127 & 51.324 & 39.315 & 43.717 & 269.000 & 16.252 \\
$\mathrm{~T}\left({ }^{\circ} \mathrm{C}\right)$ & 126 & 24.263 & 24.592 & 1.781 & 18.460 & 9.647 \\
Average & & & & & & $17.14 \%$ \\
\hline
\end{tabular}

In the present study, however, the water quality data are presented as they are without any averaging in space or time and are compared directly with the model results. All of the available data at the 15 stations (Tables 1 and 2) are used for model-data comparison.

The lake's DO typically varies between 6 and $9 \mathrm{mg} / \mathrm{l}$ and shows no sign of hypoxia or anoxia. Algae blooms can occur in the summer and early fall (from June to September). Further analysis of the model results revealed that Lake Okeechobee can be nitrogen-limited in the summer (Jin et al. 2007). From time to time, light can also limit algae growth when sediment concentrations are high. The availability of nitrogen and light may control algae growth in the lake in the summer. The light is more likely to limit algal growth during the winter. Water temperature may also limit algal growth in the winter. Light availability appears to be an important

Table 2 Summary of station-averaged relative RMS errors (RRMSE) from 1999 to 2009

\begin{tabular}{lll}
\hline Station number & Station name & RRMSE (\%) \\
\hline 1 & LO06 & 21.8 \\
2 & LOO1 & 23.2 \\
3 & LZ40 & 17.1 \\
4 & LO05 & 22.7 \\
7 & LOO2 & 23.0 \\
8 & LOO3 & 21.1 \\
10 & LOO7 & 22.4 \\
14 & LZ30 & 21.1 \\
15 & LZ42 & 20.4 \\
16 & LZ42N & 26.2 \\
17 & PALMOUT & 24.9 \\
18 & PELMID & 24.3 \\
19 & PLN2OUT & 24.0 \\
24 & STAKEOUT & 23.3 \\
25 & TREEOUT & 22.3 \\
& Mean & $\mathbf{2 2 . 6}$ \\
\hline
\end{tabular}

limiting factor for phytoplankton production. In the summer and fall, nitrogen appears to be the dominant limiting factor for algae production (Aldridge et al. 1995; Jin et al. 2007).

Transect data for SAV model calibration and verification SAV data were collected both temporally and spatially. On a monthly basis, SAV was sampled along 16 transects that extend from the littoral zone to deeper waters in the south, west, and north nearshore regions known to support SAV under favorable conditions (Figure 3). Routine monthly transect samplings (Rodusky et al. 2005) indicate that SAV biomass declined substantially in response to the hurricanes in 2004 and 2005 (Figure 4). In the months prior to the 2004 hurricanes, average SAV biomass ranged from 19.1 to $35.6 \mathrm{~g}$ dry wt. $\mathrm{m}^{-2}$. Immediately after two hurricanes passed near the lake in 2004, average SAV biomass declined to about $5.4 \mathrm{~g}$ dry wt. $\mathrm{m}^{-2}$, probably as a result of direct wind wave (Jin and Wang 1998), large seiche), and lake-stage impacts. Further declines occurred as a result of the passage of Hurricane Wilma over the lake in 2005, with biomass averaging less than $0.1 \mathrm{~g}$ dry wt. $\mathrm{m}^{-2}$. Biomass values remained low throughout 2006 and into early 2007. The SAV recovery started in 2007 due to a prolonged drought which resulted in historically low lake stages. During low water levels, light can reach the lake bed and help the SAV seeds to germinate even when the water is still turbid, which was the hurricane's prolonged effect (Jin et al. 2011). This recovery process lasted for 2 years, and the SAV was considered to have made a full recovery in the summer of 2009 (Jin et al. 2011). Two seasons of SAV biomasses are presented in Figure 4: the summer season is from April to October while the winter is defined as November to March of the following year. These biomass data were collected from 2000 to 2009.

On a yearly basis, the entire nearshore region is mapped during the summer to determine the spatial extent of each SAV species. The spatial extent of the hurricane damage to the SAV is evident from the results of the annual 


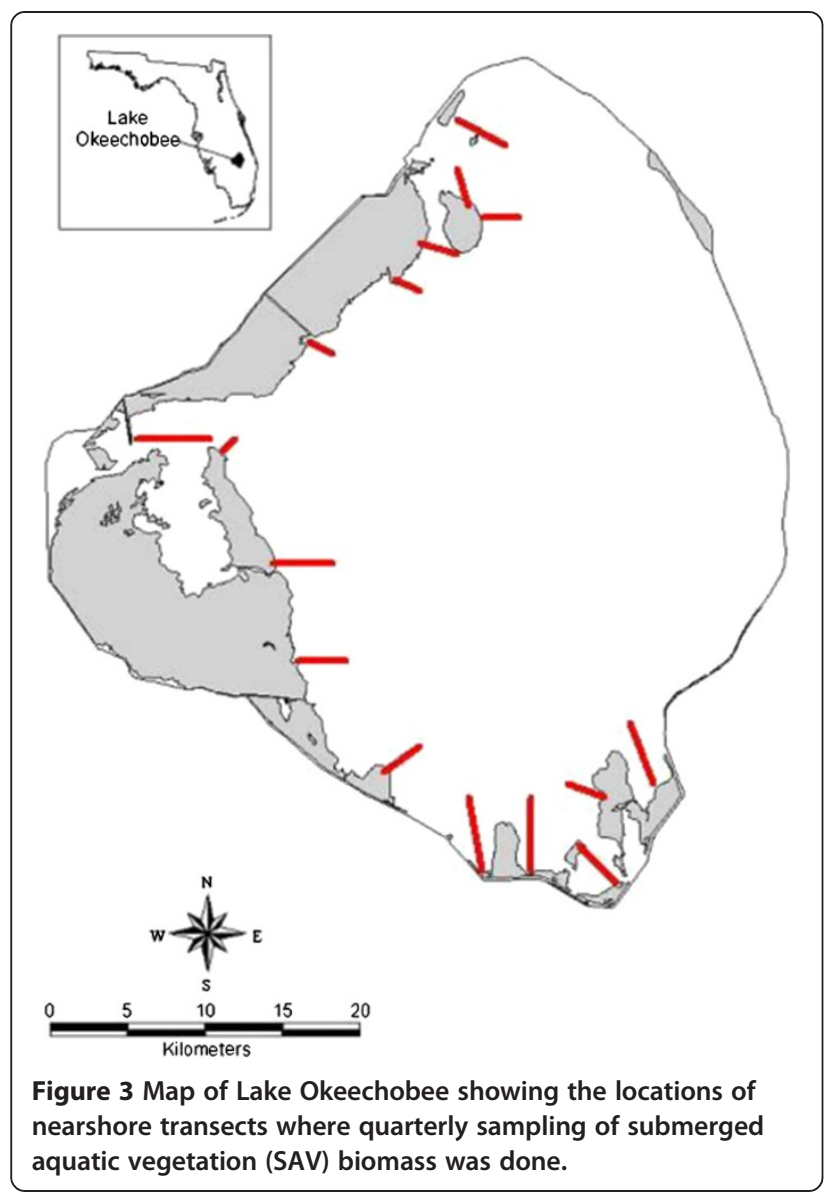

nearshore transects where quarterly sampling of submerged aquatic vegetation (SAV) biomass was done. mapping surveys (Figure 5). SAV coverage declined from 54,875 ac in late summer 2004 (prior to Hurricanes Frances and Jeanne) to 10,872 ac in late summer 2005 (post Hurricanes Frances and Jeanne). A further reduction in coverage occurred post-Hurricane Wilma with SAV occupying less than 3,000 ac in late summer 2006. Since the beginning of water year 2007 (May 2006April 2007), the lake has experienced more severe drought conditions than that of the 2000-2001 drought years. Many of the nearshore transect sites became dry during the spring and early summer of 2007. However, the low water levels led to improved light conditions at the offshore transect sites, and the SAV likewise moved offshore, expanding the littoral zone and marsh habitat.

In response to these improved conditions, average SAV biomass slowly increased during the late summer and fall of 2007 and peaked at $9.1 \mathrm{~g}$ dry wt. $\mathrm{m}^{-2}$ in October 2007. An increase in the total acreage of SAV to 28,180 ac was documented during the annual mapping (Figure 5). The full extent of SAV recovery from the 2007-2008 drought is reflected in 2009. There are a total of 10 years of SAV values (multiple areas across the lake) available for statistical analysis.

In this SAV model, nitrogen and phosphorus in SAV biomass are quantified as fractions of the carbonaceous biomass. Nutrients are taken up in stoichiometric relation to net production. Proportions removed from the water column and sediments are determined by the relative nutrient limits in each pool. SAV respiration releases nutrients back into the sediment bed and water column.

The SAV model has direct linkages with the water quality model, including (1) a link between growth and decay of SAV and the nutrient pool of the water quality model; (2) a link between photosynthesis and respiration

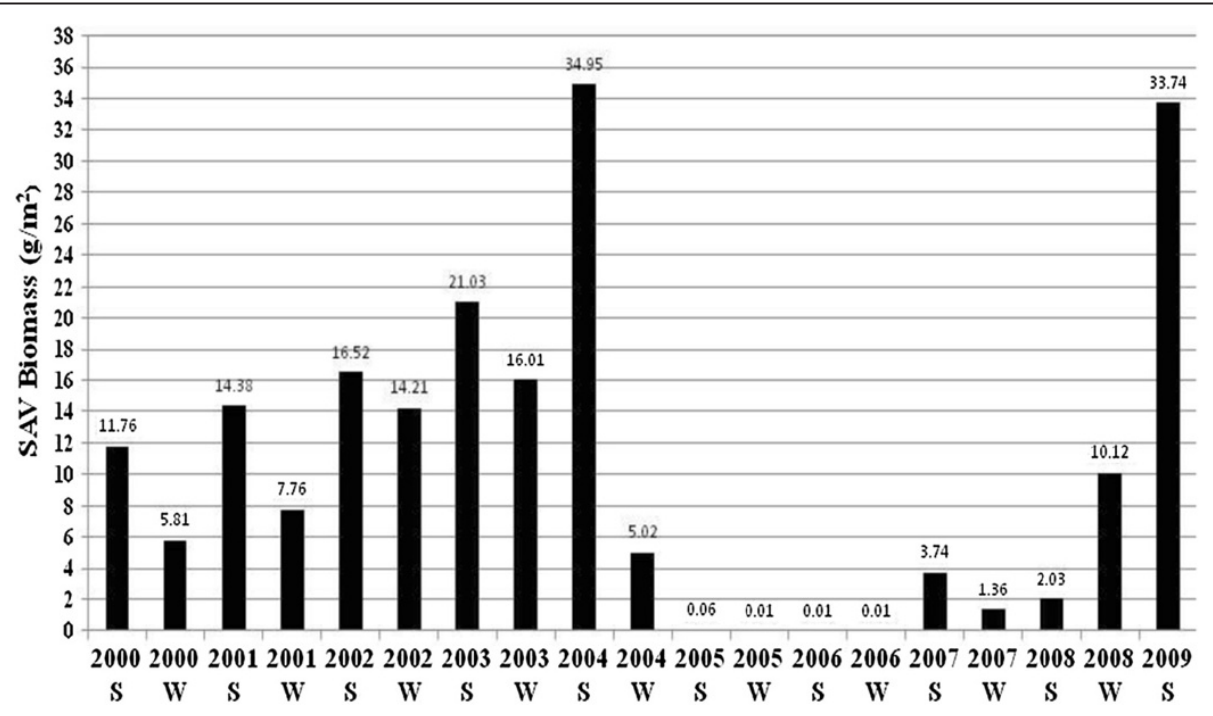

Figure 4 SAV averaged seasonal transect biomass from January 2000 to December 2009. 


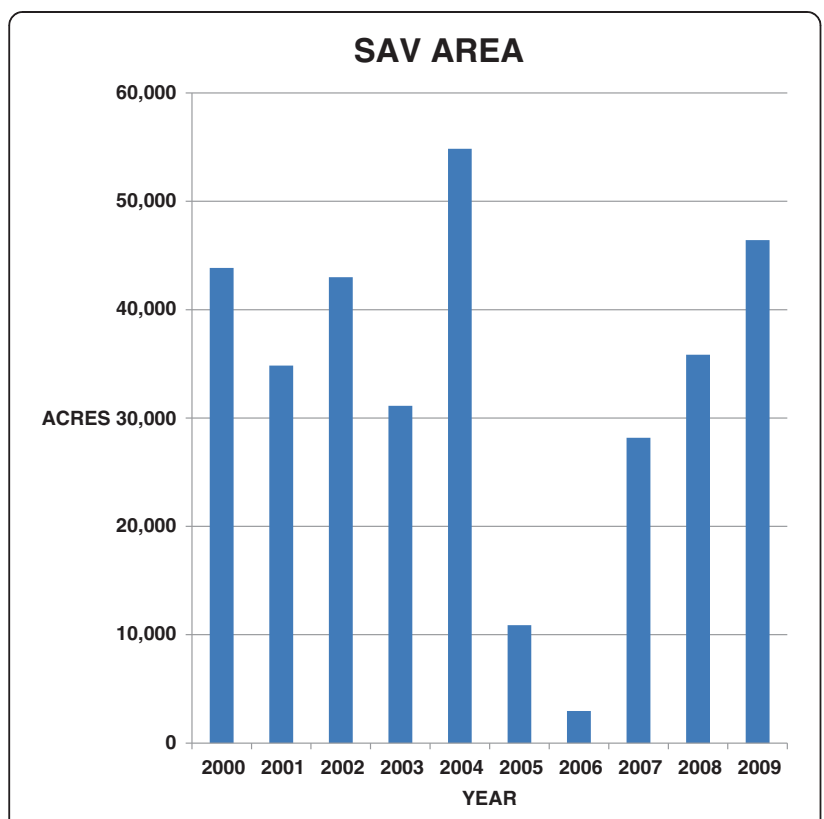

Figure 5 Total SAV area (acres) from 2000 to 2009.

of SAV and DO dynamics; and (3) the way in which settling of particulate organic matter (POM) and nutrient uptake affect nutrient levels in the water column and in the sediment bed (Cerco et al. 2002).

The measured water quality data used in this study have passed SFWMD's QA/QC procedures. The data were retrieved from the SFWMD's DBhydro database (SFWMD 2011), which includes water quality parameters observed at the 15 stations (Figure 2) used for model-data comparison.

\section{SAV model algorithm}

Since the lake is relatively shallow (mean depth $<3 \mathrm{~m}$ ), numerical tests indicate that five equally spaced vertical layers in the LOEM are sufficient to resolve the vertical structure of the lake. The model grid contains 2,123 horizontal grid cells. The horizontal length (DX) and longitudinal length (DY) of each cell are constants with values of $912 \mathrm{~m}(2,992 \mathrm{ft})$ and $923 \mathrm{~m}(3,028 \mathrm{ft})$, respectively. The state-of-the-art SAV model with completed calibration (2000-2004) (Jin et al. 2007) and the LOEM served as tools to provide simulated SAV results in the lake under different management scenarios. SAV data collection measured over 10 years and analysis with modeling results will be presented and discussed.

SAV is often a desirable component of shallow lakes and wetlands. Management activities are often directed to ensure its continual presence. SAV is an important habitat, providing refuge to juvenile fish and shellfish and providing a food source for fish and waterfowl. Consequently, the assessment of SAV provides a direct link between water quality (nutrients, chlorophyll $a$, and suspended sediments) (Chang et al. 2012) and ecologically and economically important species. The extent of SAV in a water system varies directly with water clarity and inversely with water depth. The amount of total suspended solids, nutrients, and algae in the water column affects water clarity and plays a major role in controlling SAV growth. The extent of SAV coverage is often an important performance measure for evaluating the success of nutrient reduction efforts and water quality management in an ecosystem.

SAV takes up large quantities of nutrients, which are contained in the SAV biomass throughout the SAV growth seasons. As the SAV dies and decays in fall and winter, it slowly releases the nutrients back into the water column at a time when algal blooms pose less of a problem. In addition, SAV produces oxygen in the water column, which is beneficial to aquatic organisms, especially to benthic organisms. SAV provides environmental benefits to the lake, and can (1) produce a net increase in DO; (2) increase resistance drag to reduce flow speed; (3) reduce wave height and steepness; (4) reduce shear stress at the sediment bed and shelter the sediment bed; (5) reduce suspended sediment concentration, which improves water clarity; (6) take up nutrients in the growing season; (7) provide a healthy ecosystem; and (8) support fish and bird populations.

Three components are required in order to simulate SAV growth (Figure 6). The first is an SAV model that describes SAV biomass growth and decay. The second is a water quality model that provides light, water temperature, nutrients, and other forcing functions to the SAV model. The third is a coupling algorithm that links the water quality model to the SAV model. This study describes a 10-year period (10/1/1999-9/30/2009), which includes two droughts and three hurricanes (Category II and III) events.

On an annual basis (typically during August), the entire SAV community is mapped at a resolutionof $1,000 \times 1,000 \mathrm{~m}$ to show the spatial distribution of SAV biomass (e.g., Figure 7, green and blue areas). It is evident that SAV abundance is not uniformly distributed in the lake. SAV abundance distribution is affected by at least three factors: area available for SAV growth, conditions for SAV growth (water depth, water clarity, nutrients), and tropical storms and hurricanes, such as Hurricane Wilma, which dramatically increased concentrations of TP and turbidity in 2005. The SAV area also appears to have dramatically decreased during two periods that had significant hurricane episodes (transition from 2005 into 2006, which may have been affected by Wilma, and the period from 2004 into 2005, which may have been affected by Hurricanes Frances and Jeanne in that year). The observed distribution of SAV in Figure 7 largely reflects the 


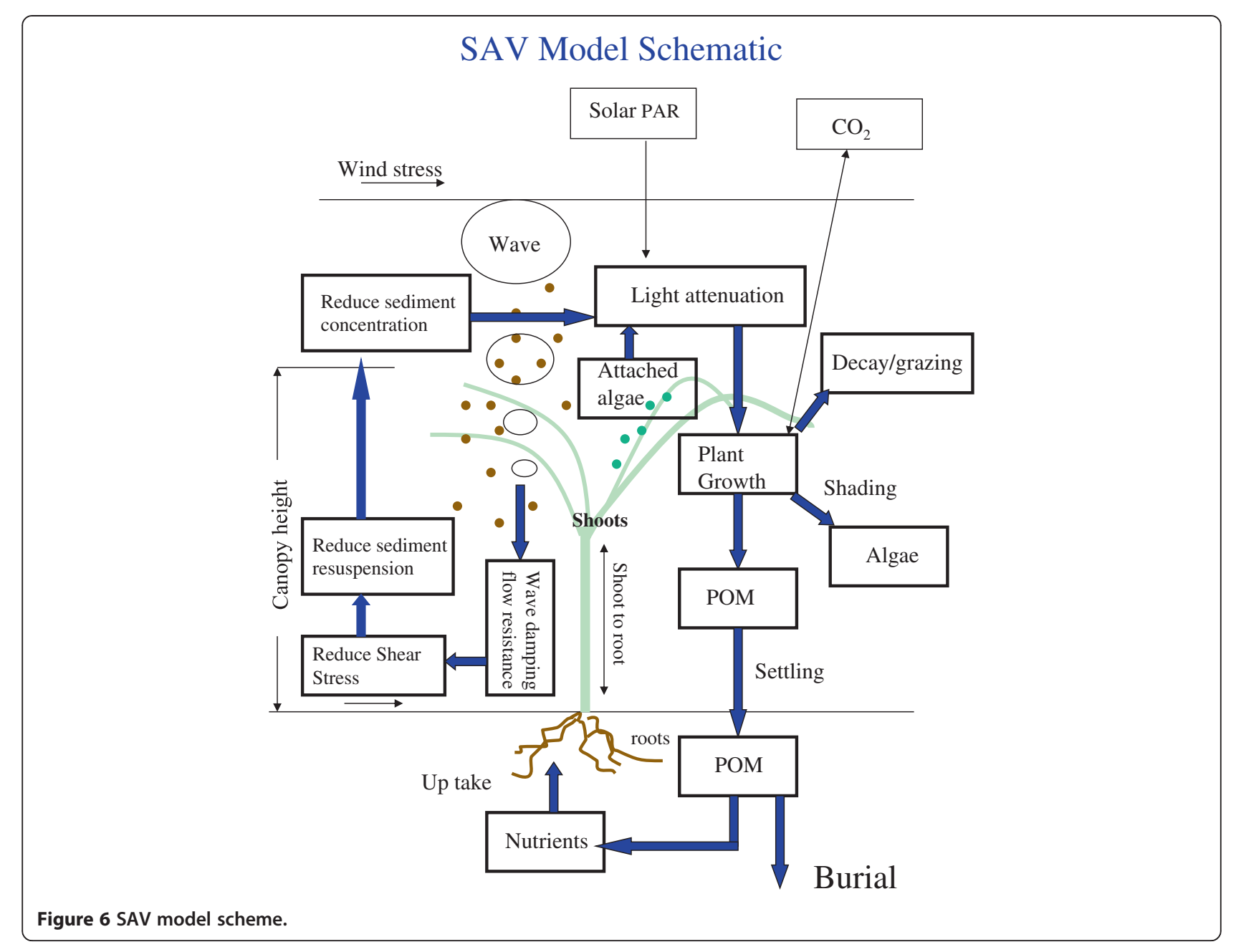

distribution of light attenuation. Figure 5 shows the SAV area for 10 years (2000-2009).

For the SAV model, a ribbon of littoral cells is created in the nearshore zone (blue and green areas). SAV is modeled in these nearshore cells and in a few other additional cells in regions that historically supported SAV. The strong hurricanes in 2004 and 2005 caused large sediment resuspension and the uprooting of SAV from the lake bed, as a result of strong current and wind waves. The modeled water depth, TSS, and algae are used to calculate the light available for SAV growth. The modeled nutrients from the LOEM water quality model are used in the SAV model.

\section{Results}

The SAV modeling sample results are summarized in Figure 8 . The first panel of this figure gives the modeled water depth at cell $(22,23)$, which is at Station PALMOUT (Figure 2) located in the nearshore zone. Figure 1 showed that the LOEM model simulated the lake water depth (and stage) very well. Therefore, it is expected that the water depth modeled at PALMOUT should represent the water depth at that location reasonably well. The variation in the water depth in this first panel will be used to explain the seasonal variation in SAV biomass and SAV acreage.

The second panel is TSS data (dot line) and model results (solid line) from 2000 to 2009. TSS ranged from 10 to $30 \mathrm{mg} / \mathrm{l}$ in the summer and 40 to $60 \mathrm{mg} / \mathrm{l}$ in the winter before the hurricane years 2004-2005. There are 95 data points with the observed data mean being 23.094 $\mathrm{mg} / \mathrm{l}$ and the modeled mean being $23.429 \mathrm{mg} / \mathrm{l}$. The RMSE is $40.383 \mathrm{mg} / \mathrm{l}$ and RRMSE 28.083\%. The dots in the third panel are the mean observed results from the SAV half-year surveys. The modeled SAV results (solid line) followed the pattern and trend of SAV growth in the simulation period. The fourth panel presents the SAV annual area survey (dot line) and modeled SAV growth area. The modeled SAV growth area (solid line) followed the pattern and trend of observed SAV growth area in the simulation period. 

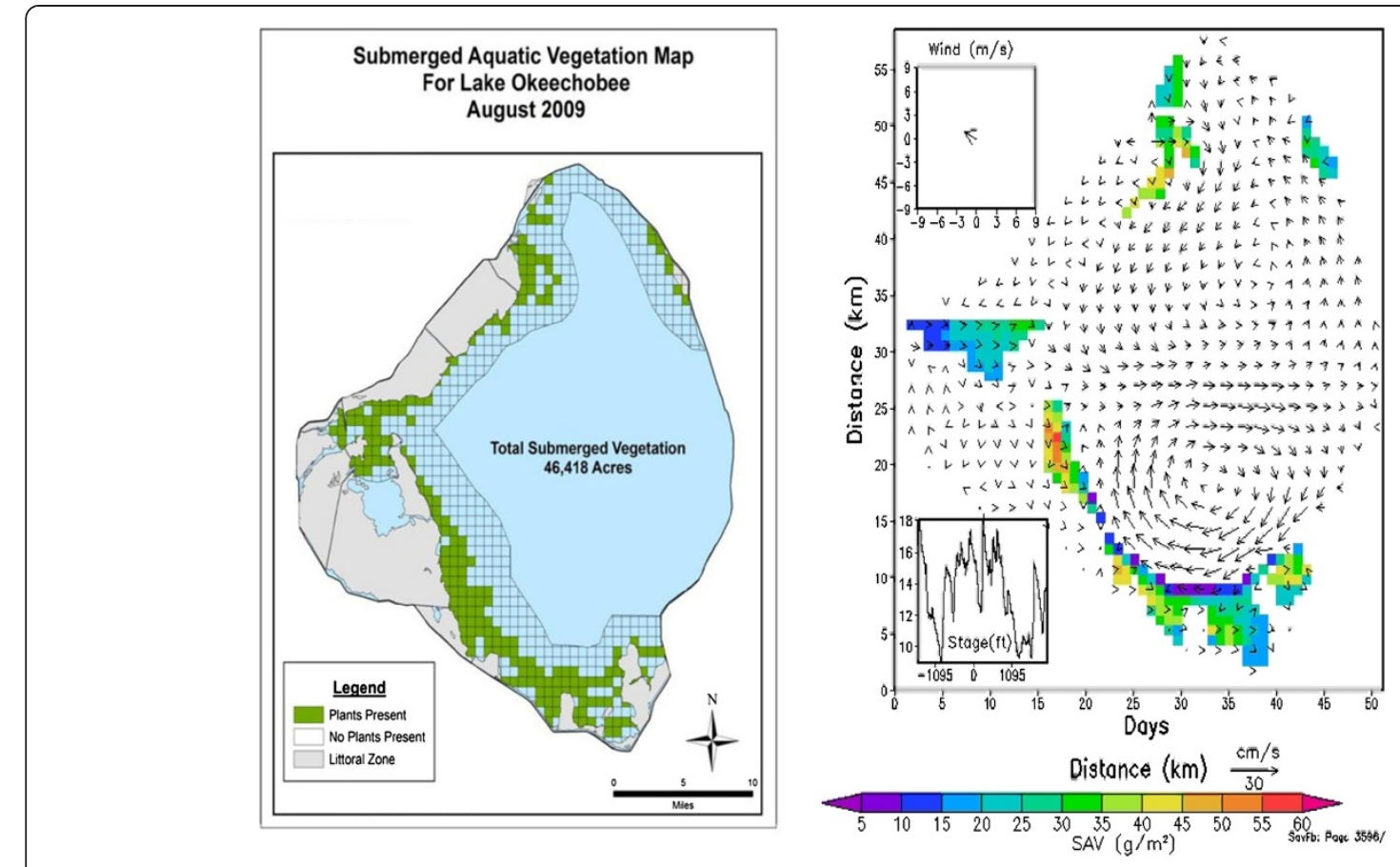

Figure 7 Summary of observed data from SAV surveys in August 2009 and model results from 8/15/2009.

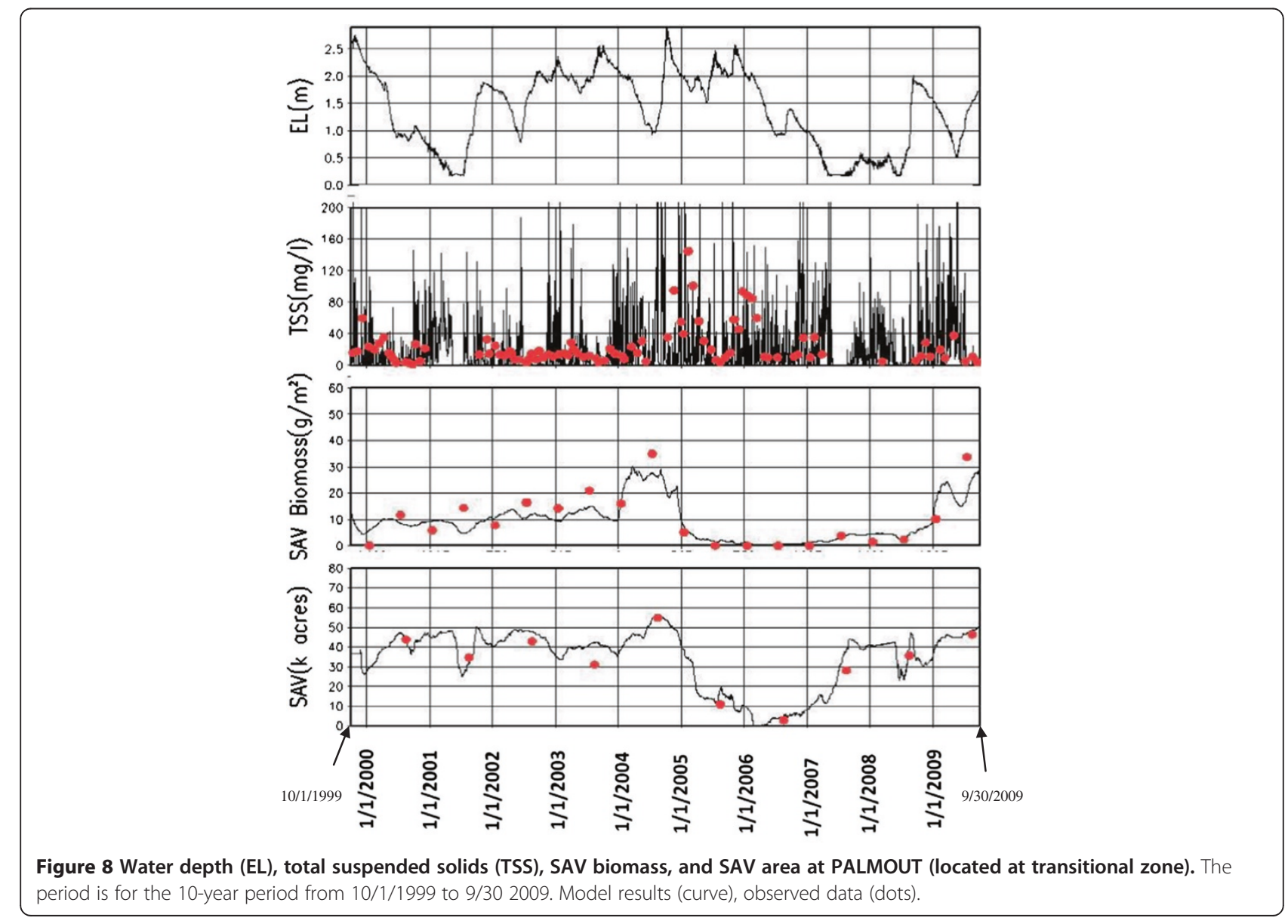


The first panel indicates that in early 2000, the water depth was very high and the SAV biomass and area (panels 3 and 4) were low (James and Havens 2005). In 2001, however, the extremely low water depth exposed a large portion of the lake bottom. The SAV biomass recovered. Shoreline areas of Lake Okeechobee have supported a large acreage of SAV in years with moderate to low water levels, but the acreage had been reduced to nearly zero following hurricane events. In 2005 and 2006, the SAV biomass was very low, primarily due to the two extraordinary hurricane seasons in 2004 and 2005. The SAV area (fourth panel) dropped to the thousands of acres and SAV biomass (third panel) was down to $0.01 \mathrm{mg} / \mathrm{l}$. As shown in Figure 8, both the model and the observed data indicate that lowering the water level generally caused widespread SAV increases in Lake Okeechobee.

TSS affects light attenuation and is another major driving factor for SAV growth in the nearshore and littoral zone area (Otsubo and Muraoka 1987; Jin and Sun 2007; Havens and James 1999). The TSS range was $10-30 \mathrm{mg} / \mathrm{l}$ in the summer and 40-60 mg/l during the winter before the hurricane years 2004-2005. The average SAV biomass before the hurricanes was 10-20 g dry wt. $\mathrm{m}^{-2}$. However, the SAV biomass fell sharply in the years after Hurricane Frances and Jeanne in 2004 and did not attain the same level of coverage until 2009. The hurricanes in 2004 and 2005 considerably increased the TSS and reduced the light transparency in the littoral and nearshore region (James et al. 2008; Havens and James 2005). This phenomenon blocked SAV and phytoplankton growth. The average SAV biomass dropped from pre-hurricane levels of approximately15 g dry wt. $\mathrm{m}^{-2}$ to $4 \mathrm{~g}$ dry wt. $\mathrm{m}^{-2}$ at the end of winter 2004 . The biomass further dropped to $0.1 \mathrm{~g}$ dry wt. $\mathrm{m}^{-2}$ after Hurricane Wilma (2005) and continued to decline to a level of $<0.02 \mathrm{~g}$ dry wt. $\mathrm{m}^{-2}$ for the rest of 2005 and 2006 due to the presence of high TSS that blocked light penetration in the water column. This situation lasted until the summer of 2007 when the drought lowered the lake stage and light was able to reach the lake bottom sediments. This3-year impact featuring high TSS and turbidity significantly stressed the lake's ecosystem and damaged the food chain of the lake to some extent (Jin et al. 2011). The SAV in the nearshore regions (transition zone), located between the littoral zone and the mud zone, was almost completely destroyed during the 2004-2005 hurricane season.

The historical drought that occurred in 2007-2008 did not change the TSS, turbidity, or total phosphorus dramatically, and the averages of these three water quality indicators continued to be higher than normal in the open water (Havens and James 1997). However, the average water depth dropped significantly during the 20072008 drought event (panel 1, Figure 8); furthermore,
TSS dropped. This historical drought drove the lake stage so low that light was able to reach the lake bed; SAV seeds were thus able to germinate and grow again in the shallow water or transition zone. The SAV growth conditions, which had been damaged by the hurricanes in 2004 and 2005, gradually improved and recovered during this drought event.

The seasonal and annual variability and trends were reasonably represented by the SAV model. Figure 7 shows the modeled SAV area on 8/15/2009; the model results compare favorably with the measured SAV area in July-August 2009. The model performed reasonably well in reproducing the spatial distribution of SAV.

\section{Discussion and conclusions}

Theoretical analysis and model sensitivity tests indicate that SAV growth is primarily controlled by light and nutrients (AEE). Light available for SAV growth decreases with water depth. Figure 8 shows that the water depth in the SAV area plays a key role in controlling the SAV biomass and SAV acreage. Generally speaking, deeper water leads to lower SAV biomass and SAV acreage, except for the two years (2005 and 2006) right after the extraordinary hurricane seasons in 2004 and 2005. The light available for SAV growth depends on water depth and turbidity. In this full scale simulation, the water depth was derived from the LOEM hydrodynamic model, and the turbidity depends on the suspended sediment concentration and algal concentration. In the past $10+$ years, the LOEM hydrodynamic model, sediment model, wind wave model, toxic model, and water quality model have been calibrated, verified, and validated. These modeling efforts provided an important foundation for the SAV modeling in this study. The enhanced LOEM can serve as a tool to provide estimates of each water quality parameter, SAV, and other variables under different nature and management scenarios.

SAV has multiple functions in a water system, especially in shallow water systems. SAV plays a critical role in stabilizing sediments, removing nutrients from the water, and providing a critical habitat for fish, wading birds, and other wildlife. The extent of SAV in a water system varies directly with water clarity and inversely with water depth. The amount of total suspended solids, nutrients, and algae in the water column affects water clarity and plays a major role in controlling SAV growth. The extent of SAV coverage is often an important performance measure for evaluating the success of nutrient reduction efforts and water quality management in an ecosystem.

During the SAV growth seasons (spring-fall), SAV takes up large quantities of nutrients, which are contained in the SAV biomass throughout the warm seasons. As the SAV dies and decays in late fall and during the winter, it slowly releases the nutrients back to the water column at 
a time when algal blooms pose less of a problem. In addition, SAV produces oxygen in the lower portion of the water column through photosynthesis, which is beneficial to aquatic organisms, especially to the benthic organisms. Specific benefits of SAV include (1) increasing total resistance to flow; (2) reducing wave height and steepness; (3) reducing shear stress at the sediment bed and sheltering the sediment bed; (4) reducing suspended sediment concentration and improving water clarity; (5) taking up nutrients in the growing season; (6) providing a healthy ecosystem (in moderation); (7) supporting fish and bird populations; and (8) producing a net increase in DO.

The theoretical analysis and model sensitivity tests indicate that SAV growth is primarily controlled by light and nutrients. As shown in Figure 8, both the model and the observed data indicate that lowering the water level generally caused widespread SAV increases in Lake Okeechobee.

\section{Competing interests}

The authors declare that they have no competing interests.

\section{Authors' contributions}

KRJ carried out the data analysis and drafted the manuscript. ZGJ performed the model runs and statistical analysis. Both authors read and approved the final manuscript.

\section{Acknowledgements}

The authors wish to thank the Okeechobee Data Collection Team for SAV data collection. The authors also wish to thank Amy Peters for preparing Figures 2 and 3 .

\section{Author details}

'South Florida Water Management District, P.O. Box 24680, West Palm Beach, FL 334164680, USA. ²Department of Civil Engineering, Catholic University of America, Pangborn Hall, Room G12, Washington, DC 20064, USA.

Received: 10 September 2012 Accepted: 10 May 2013

Published: 15 July 2013

\section{References}

AEE (2012) CERP ASR Lake Okeechobee submerged aquatic vegetation model enhancement and application. Technical report to South Florida Water Management District. Applied Environmental Engineering, LLC and Camp Dresser \& McKee Inc, Virginia

Aldridge FJ, Phlips EJ, Schelske CL (1995) The use of nutrient enrichment bioassays to test for spatial and temporal distributions of limiting factors affecting phytoplankton dynamics in Lake Okeechobee, Florida. In: Aumen NG, Wetzel RG (ed) Advances in limnology. Schweizerbart, Stuttgart, Germany

Cerco CF, Cole T (1994) Three-dimensional eutrophication model of Chesapeake Bay. volume i: main report. Technical report EL-94-4. US Army Corps of Engineers Waterways Experiment Station, Vicksburg, MS

Cerco CF, Moore K (2001) System-wide submerged aquatic vegetation model for Chesapeake Bay. Estuaries 24(4):522-534

Cerco CF, Billy HJ, Wang HV (2002) Tributary refinements to the Chesapeake Bay Model. Technical report ERDC TR-02-4. U.S. Army Corps of Engineers Waterways Experiment Station, Vicksburg, MS

Chang NB, Yang JMA, Jin KR, James RT (2012) Spatiotemporal pattern validation of chlorophyll-a concentrations in Lake Okeechobee, Florida, using a comparative MODIS image mining approach. Int J Remote Sens 33(7):2233-2260

Dean RG, Dalrymple RA (1991) Water wave mechanics for engineers and scientists. World Scientific, Singapore
Dennison WC, Orth RJ, Moore KA, Stevenson JC, Carter KS, Bergstrom PW, Batiuk RA (1993) Assessing water quality with submersed aquatic vegetation. Bioscience 43:86-94

Hamrick JM (1992) Estuarine environmental impact assessment using a three-dimensional circulation and transport model. In: Spaulding ML (ed) Estuarine and coastal modeling, proceedings of the 2nd international conference. American Society of Civil Engineers, New York, pp 292-303

Hamrick JM (1994) Linking hydrodynamic and biogeochemical transport models for estuarine and coastal waters. In: Spaulding ML (ed) Estuarine and coastal modeling, proceedings of the 3rd international conference. American Society of Civil Engineers, New York, pp 591-608

Hamrick JM, Wu TS (1997) Computational design and optimization of the EFDC/ HEM3D surface water hydrodynamic and eutrophication models. In: Delich G, Wheeler MF (ed) Next generation environmental model and computational methods. Society of Industrial and Applied Mathematics, Philadelphia, pp 143-161

Havens KE (2003) Submerged aquatic vegetation correlations with depth and light attenuating materials in a shallow subtropical lake. Hydrobiologia 493:173-186

Havens KE, Gawlik DE (2005) Lake Okeechobee conceptual model. Wetlands 25:908-925

Havens KE, James RT (1997) A critical evaluation of phosphorus management goals for Lake Okeechobee, Florida, USA. Lake Reservoir Manage 13:292-301

Havens KE, James RT (1999) Localized changes in transparency linked to mud sediment expansion in Lake Okeechobee, Florida: ecological and management implications. Lake Reservoir Manage 15:54-69

Havens KE, James RJ (2005) The phosphorus mass balance of Lake Okeechobee, Florida: implications for eutrophication management. Lake Reservoir Manage 21:139-148

Havens KE, Walker WW (2002) Development of a total phosphorus concentration goal in the TMDL process for lake Okeechobee, Florida (USA). Lake Reservoir Manage 18:227-238

Havens KE, Bierman VJ, Jr, Flaig EG, Hanlon C, James RT, Jones BL, Smith VH (1995) Historical trends in the Lake Okeechobee ecosystem. VI. Synthesis. Arch HydrobiolSuppl 107:101-111

Havens KE, Bull LA, Warren GL, Crisman TL, Phlips EJ, Smith JP (1996a) Food web structure in a subtropical lake ecosystem.Oikos 75:20-32

Havens KE, Aumen NG, James RT, Smith VH (1996b) Rapid ecological changes in a large subtropical lake undergoing cultural eutrophication. Ambio 25:150-155

Havens KE, East TL, Rodusky AJ, Sharfstein B (1999) Littoral periphyton responses to nitrogen and phosphorus: an experimental study in a subtropical lake. Aquat Bot 63:267-290

Havens KE, Beaver JR, East TL, Rodusky AJ, Sharfstein B, Amand AS, Steinman AD (2001) Nutrient effects on producers and consumers in the littoral plankton and periphyton of a subtropical lake. Arch Hydrobiol 152:177-201

Havens KE, Sharfstein B, Brady MA, East TL, Harwell MC, Maki RP, Rodusky AJ (2004a) Recovery of submerged plants from high water stress in a large subtropical lake in Florida, USA. Aquat Bot 78:67-82

Havens KE, Sharfstein B, Rodusky AJ, East TL (2004b) Phosphorus accumulation in the littoral zone of a subtropical lake. Hydrobiologia 517:15-24

Havens KE, Fox D, Gornak S, Hanlon C (2005) Aquatic vegetation and largemouth bass population responses to water-level variations in Lake Okeechobee, Florida (USA). Hydrobiologia 539:225-237

James RT, Havens KE (2005) Outcomes of extreme water levels on water quality of offshore and nearshore regions in large shallow subtropical lake. ArchHydrobiol 163:225-239

James RT, Chimney MJ, Sharfstein1 B, Engstrom DR, Schottler SP, East LT, Jin KR (2008) Hurricane effects on a shallow lake ecosystem, Lake Okeechobee, Florida (USA). Fund ApplLimnol Arch Hydrobiol 172(4):73-287

Ji ZG (2008) Hydrodynamics and water quality: modeling rivers, lakes, and estuaries. Wiley, Hoboken

Ji ZG, Jin KR (2006) Gyres and seiches in a large and shallow lake. J Great Lakes Res 32:764-775

Jin KR, Ji ZG (2001) Calibration and verification of a spectral wind-wave model for Lake Okeechobee. J Ocean Eng 28(5):573-586

Jin KR, Ji ZG (2004) Case study: modeling of sediment transport and wind-wave impact in Lake Okeechobee. J Hydraulic Eng ASCE 130(11):1055-1067

Jin KR, Ji ZG (2005) Application and validation of a 3-D model in a shallow lake. J Waterway Port Coastal Ocean Eng ASCE 131(5):213-225 
Jin KR, Sun D (2007) Sediment resuspension and hydrodynamics in Lake Okeechobee during the late summer. J ASCE EngMech 133(8):899-910

Jin KR, Wang KH (1998) Wind generated waves in Lake Okeechobee. J AWRA 34(6):1-12

Jin KR, Hamrick JH, Tisdale T (2000) Application of a three-dimensional hydrodynamic model for Lake Okeechobee. J Hydraulic Eng ASCE 126:758-771

Jin KR, Ji ZG, Hamrick JH (2002) Modeling winter circulation in Lake Okeechobee, Florida. J Waterway Port Coastal Ocean Eng ASCE 128(3):114-125

Jin KR, Ji GZ, James RJ (2007) Three dimensional water quality modeling of a large shallow lake. J Great Lakes Res 33(1):28-45

Jin KR, Chang NB, Ji ZG, James RJ (2011) Hurricanes affect the sediment and environment in Lake Okeechobee. JCrit Rev EnvironSciTechnol 41(S1):382-394

Martin JL, McCutcheon SC (1999) Hydrodynamics and transport for water quality modeling. CRC Press, Boca Raton

Murphy TH, Yesaki I (1983) Co-precipitation of phosphate and calcite in a naturally eutrophic lake. LimnolOceanogr 28:58-67

Otsubo K, Muraoka K (1987) Field studies on physical properties of sediment and sediment resuspension in Lake Kasumigaura. Jpn J Limnol 48:131-138

Phlips EJ, Aldridge FJ, Hansen P, Zimba V, Inhat J, Conroy M, Ritter P (1993) Spatial and temporal variability of trophic state parameters in a shallow subtropical lake (Lake Okeechobee, Florida, USA). ArchHydrobiol 128:437-458

Rodusky AJ, Sharfstein B, East TL, Maki RP (2005) A comparison of three methods to collect submerged aquatic vegetation in a shallow lake. Environ Monit Assess 110:87-97

Scheffer M (1998) Ecology of shallow lakes. Chapman and Hall, London

Sheng PJ, Davis R, Sun D, Qiu C, Christian D, Park K, Kim T, Zhang Y (2001) Application of an integrated modeling system for estuarine and coastal ecosystems to Indian River Lagoon, Florida. In: Spaulding ML (ed) Estuarine and coastal modeling, proceedings of the 7th international conference. American Society of Civil Engineers. ASCE Estuarine and Coastal Modeling, New York, pp 329-343

Sheng YP, Christian D, Kim T (2003) Indian River Lagoon pollutant load reduction model development project, volume $\mathrm{V}$ : a submerged aquatic vegetation (SAV) model CH3D-SAV. University of Florida, Florida

Scheffer M (1989) Alternative stable states in eutrophic shallow freshwater systems: a minimal model. Hydrobiol Bull 23:73-85

Scheffer MM, Van den Berg A, Breukelaar C, Breukers H, Coops RD, Meijer ML (1994) Vegetated areas with clear water in turbid shallow lakes. Aquat Bot 49:193-196

SFWMD (2011) DBhydrobrowser user documentation. South Florida Water Management District, West Palm Beach, FL

USEPA (1999) Review of potential modeling tools and approaches to support the BEACH program. EPA 823-R-99-002. U.S. Environmental Protection Agency, Office of Science and Technology, Washington, DC

Vermaat JE, Santamaria L, Roos PJ (2000) Water flow across and sediment trapping in submerged macrophyte beds of contrasting growth form. ArchHydrobiol 148:549-562

doi:10.1186/2192-1709-2-23

Cite this article as: Jin and Ji: A long term calibration and verification of a submerged aquatic vegetation model for Lake Okeechobee. Ecological Processes 2013 2:23

\section{Submit your manuscript to a SpringerOpen ${ }^{\circ}$ journal and benefit from:}

- Convenient online submission

- Rigorous peer review

- Immediate publication on acceptance

- Open access: articles freely available online

- High visibility within the field

- Retaining the copyright to your article

Submit your next manuscript at $\gg$ springeropen.com 